Фармацевтична технологія, біофармація, гомеопатія Pharmaceutical technology, biopharmacy, homeopathy

Рекомендована д. фрармац. наук. профр. Т. Г. Калинюком УДК 615.071: 615.465.1: 616-006.04.

DOI 10.11603/2312-0967.2017.1.7557

\title{
ДОСЛІДЖЕННЯ СКЛАДУ ЛІПІДНОЇ МЕМБРАНИ ПРИ СТВОРЕННІ ЛІПОСОМ ІЗ IPИНОТЕКАНОМ
}

\author{
(c) О. В. Стадніченко ${ }^{1}$, Ю. М. Краснопольський ${ }^{2}$, Т. Г. Ярних ${ }^{1}$ \\ ${ }^{1}$ Національний фрармацевтичний університет, Харків \\ ${ }^{2}$ Національний технічний університет «Харківський політехнічний інститут», Харків \\ alstn@mail.ru
}

\begin{abstract}
Мета роботи. Вивчити вплив складу ліпідної мембрани на ступінь інкапсуляції та розмір наночасток при створенні ліпосом з іринотеканом.

Матеріали і методи. Використовували реактиви фрірм Lipoid (Німеччина) та Sigma-Aldrich (США), прилади Вuсhi 210, Zetasizer Nano ZS, Minim2 з касетами із верхньою межею відсікання 30 кДа, BEPX Shimadzu LC-20. Ліпосоми з іринотеканом отримували методом «хімічного градієнта».

Результати й обговорення. Для створення ліпосом 3 іринотеканом було досліджено ліпідні мембрани із різним співвідношенням фосфратидилхолін / холестерин. Визначено, що при зростанні масового співвідношення холестерину в мембрані покращується ступінь інкапсуляції іринотекану при використанні методу «хімічного градієнта». 3 іншого боку, при масовому співвідношенні фросфратидилхолін / холестерин 75/25 та 70/30 неможливо позбутись часток із розмірами понад 1000 нм, що неприпустимо з точки зору впровадження технології.

Висновки. Проведено експеримент із дослідження оптимального складу ліпідної мембрани із використанням трьох типів кріопротектора. Досліджено ліпосомальні мембрани із співвідношенням ліпідів фросоратидилхолін / холестерин: 85/15; 80/20; 75/25; 70/30 за показником розміру ліпосом та інкапсуляції іринотекану у ліпосоми. Оптимальними визначено ліпосоми із співвідношенням ліпідів 80/20 відповідно. Окреслено шляхи підвищення ступеня інкапсуляції.
\end{abstract}

Ключові слова: ліпосоми; іринотекан; ліпідний бішар; фоссфатидилхолін; холестерин; гомогенізація методом високого тиску.

Вступ. Ліпосоми як фрізичні об'єкти були відкриті на початку 60-х років минулого сторіччя і являють собою штучні сорероїди. Внутрішнє водне середовище в ліпосомах оточене мембраною, яка складається із бішару фроссроліпідів, які перебувають у стані рідкого кристалу [1]. Розмір ліпосом, які застосовують у фрармацевтичній промисловості, коливається від 30 до 200 нм. Навіть зараз, більш ніж через півсторіччя після винаходу, ліпосоми є важливою платорормою створення нових лікарських, діагностичних та дослідницьких засобів [2, 3]. Унікальна здатність інкапсулювати як гідрофрільні, так і гідрофобні молекули робить ліпосоми універсальним інструментом для доставки лікарських речовин при проведенні терапії [4].

В українській фрармацевтичній промисловості широко використовують ліпосоми як носія для лікарських речовин. Так, на Харківському підприємстві «Біолік» було розроблено низку ліпосомальних препаратів. Це такі препарати, як «Ліпін», «Ліолів», «Антраль», «Ліпофрлавон», «Ліподокс» [5].

Звичайно, у фрармацевтичній практиці, ліпосоми використовують як носії для речовин, які не розчинні у воді, чи речовин, які проявляють токсичні та по- дразнювальні едекти при введенні в організм людини. Більшість цих речовини - цитостатики, які використовують при терапії онкологічних хвороб. Створення ліпосомальних фрорм таких препаратів $\epsilon$ одним із шляхів зменшення токсичного впливу на організм пацієнта [6].

Включення до ліпосом речовин, що проявляють токсичні ефекти, зменшує подразнення судин у місці введення, а також впливає на спрямованість ліпосом, «навантажених» лікарським засобом до онкологічно змінених органів. Такий ефект має назву «еnhanced permeability and retention (EPR) effect» - есрект підвищеної проникненості та утримання - та спостерігається у пухлинах за рахунок розвиненої васкуляризації капілярів, що спричинено швидким ростом, та, як наслідок - нещільним вистиланням клітинного ендотеліального шару судин [7].

Лікарська речовина іринотекан, структура якого наведена на рисунку $1, €$ сучасним цитостатичним засобом. Він $€$ напівсинтетичною похідною камптотецину - алкалоїду природного походження, який видобувається із деревини дерева Camptotheca accuminata [8].

ISSN 2312-0967. Фармацевтичний часопис. 2017. № 1 
Фармацевтична технологія, біофармація, гомеопатія Pharmaceutical technology, biopharmacy, homeopathy

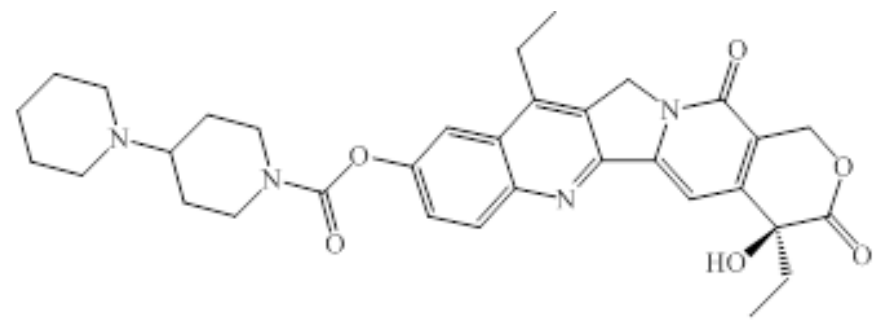

Рис. 1. Структурна фрормула іринотекану.

Фармакологічна дія іринотекану зумовлена його взаємодією із топоізомеразою І. Молекула іринотекану при введенні в організм взаємодіє із комплексом ДНК-топоізомераза I і перешкоджає процесу синтезу ДНК. Це призводить до неможливості реплікації ДНК i, як наслідок, до загибелі клітини [9]. Під час застосування іринотекану у вигляді розчину для ін'єкцій спостерігаються небажані токсичні прояви, які суттєво зменшують якість життя пацієнта, та в деяких випадках необхідно зменшити дозу препарату, що негативно впливає на якість терапії в цілому $[10,11]$.

Створення ліпосом 3 іринотеканом сприятиме зменшенню токсичного впливу на організм людини під час лікування, покращить стан пацієнтів та дасть можливість збільшувати дози препарату без розвитку побічних ефректів.

Метою роботи було дослідження складу ліпідної мембрани ліпосомальної ліофрілізованої форми іринотекану для отримання стабільних розмірів та максимальних значень інкапсуляції активної речовини.

Матеріали і методи. Для виготовлення ліпосом використовували яєчний фосфратидилхолін виробництва фрірми Lipoid (Німеччина); холестерин, трегалозу, мальтозу, лактозу - виробництва фрірми SigmaAldrich (США). Ліпосоми отримували методом «хімічного градієнта». Ліпідну плівку отримували на ротаційному випарнику Buchi 210 із вакуум контролером, при остаточному тиску 15 мм рт. ст. Для гомогенізації використовували метод екструзії високим тиском. Як внутрішній буфер використовували цитратний буферний розчин. Розмір ліпосом визначали методом лазерної дисракції на приладі Malvern Instruments Zetasizer Nano ZS. Ультрафрільтрацію для створення «хімічного градієнта» проводили на установці Minim 2, фрірми PALL. Використовували ультрафрільтраційні касети із верхньою межею відсікання 30 кДа. Визначення ступеня інкапсуляції проводили методом BEPX на приладі Shimadzu LC-20, відповідно до раніше розробленої методики [12].

Результати й обговорення. Від складу ліпідної мембрани залежать характеристики отриманих ліпосом, їх стабільність упродовж терміну зберігання, здатність утримувати всередині лікарську речовину, стійкість до ліофрілізації та регідратації [13]. 3 одного боку, мембрана повинна мати задовільну жорсткість, оскільки це впливає на утримування діючої речовини, стійкість до ліофрілізації та регідратації, з іншого боку, мембрана повинна забезпечувати можливість пружньої дефрормації ліпосом на етапі стерильної фрільтрації через стерилізуючі фрільтри із розміром пор 0,22 мкм.

Як основний матеріал мембрани обрано фросфоліпід природного походження фоссратидилхолін, який брали із жовтків курячих яєць. Як модифрікатор, який регулює жорсткість мембрани, використовували холестерин.

Проведено скринінговий експеримент із вивчення ліпідної мембрани із співвідношенням фосоратидил / холестерин: 100 / 0; 95 / 5; 85 / 15 та 70 / 30. Різниця в значенні $\mathrm{pH}$ при створені «хімічного градієнта» склала 1,3 одиниці. Ліпосоми піддавали екструзії до одержання часток із розмірами менше 200 нм. До отриманих ліпосом додавали кріопротектор лактозу, трегалозу чи мальтозу в кількості 2 \% масових. Загальна концентрація ліпідів в емульсії після гомогенізації складала 15 мг/мл. Для порівняльної оцінки стійкості отриманих ліпосом до циклу ліофрілізації / регідратації проводили ліофрільне сушіння за режимом, наведеним на рисунку 2.

До та після ліосрілізації було визначено ступінь інкапсуляції іринотекану. Результати досліджень наведено у таблиці 1.

Із даних таблиці 1 видно, що із збільшенням вмісту холестерину збільшується ступінь інкапсуляції. Експеримент 4 показав найвищі значення ступеня інкапсуляції як до, так і після ліофілізації. Але при співвідношенні фросфатидилхолін / холестерин 70/30 \% масових спостерігається ускладнення фрільтрації через фрільтр із діаметром пор 0,22 мкм. Також під час аналізу розміру часток методом лазерної дисрракції було виявлено наявність часток із діаметром понад 1000 нм, що свідчить про неоднорідність емульсії, а також впливає на якість проведення стерильної фрільтрації.

Оскільки було встановлено, що мембрана зі складом фросоратидилхолін / холестерин 85/15 придатна для створення ліпосом, а мембрана фоосфатидилхолін / холестерин 70/30 хоч і має кращі показники інкапсуляції - не забезпечує відсутності часток більше 1000 нм, було вирішено повторити експеримент із дослідження мембран із проміжним складом ліпідів. Також необхідно визначити, що трегалоза як кріопротектор показала найкращий показник ступеня інкапсуляції.

ISSN 2312-0967. Pharmaceutical review. 2017. № 1 
Фармацевтична технологія, біофармація, гомеопатія

Pharmaceutical technology, biopharmacy, homeopathy

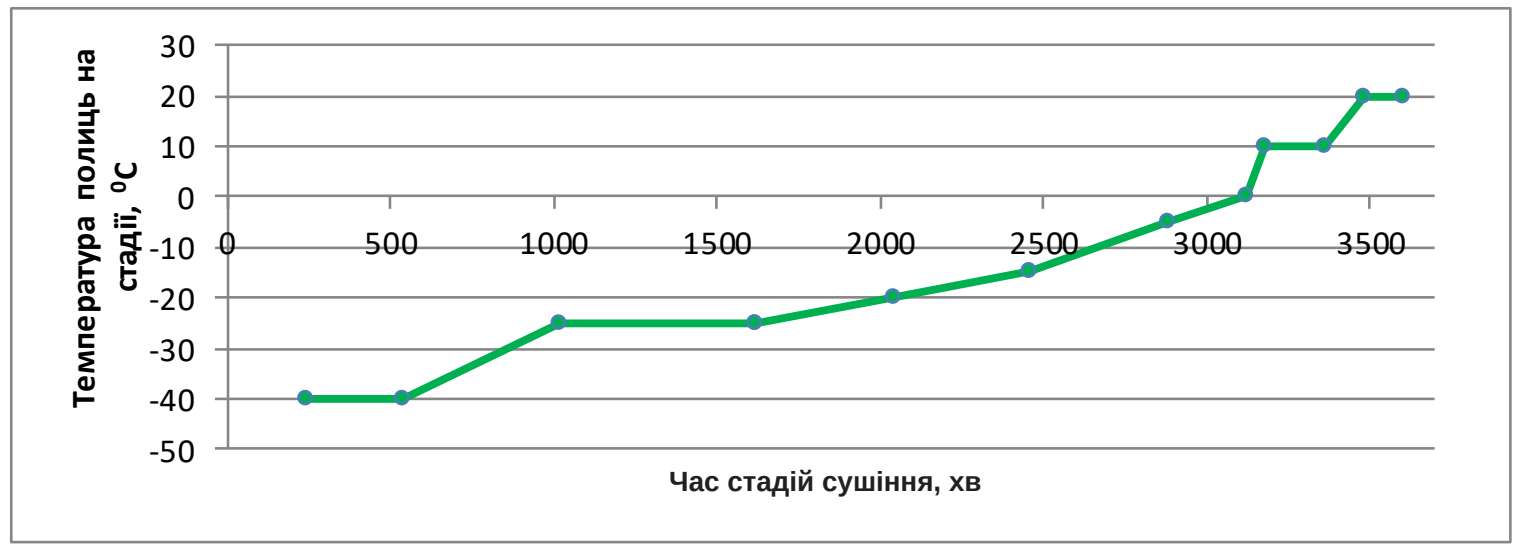

Рис. 2. Графрік режиму ліофільного сушіння при скринінгових випробуваннях.

Таблиця 1. Ступінь інкапсуляції залежно від складу ліпосом. Скринінговий експеримент

\begin{tabular}{|c|c|c|c|c|}
\hline $\begin{array}{l}\text { № } \\
\text { 3/ח }\end{array}$ & $\begin{array}{c}\text { Склад ліпідів: фоссратидилхолін / } \\
\text { холестерин, \% масові }\end{array}$ & $\begin{array}{c}\text { Ступінь інкапсуляції } \\
\text { до ліофрілізації, \% }\end{array}$ & $\begin{array}{c}\text { Доданий } \\
\text { кріопротектор }\end{array}$ & $\begin{array}{l}\text { Ступінь інкапсуляції } \\
\text { після ліофрілізації, \% } \\
\end{array}$ \\
\hline \multirow{3}{*}{1} & \multirow{3}{*}{ ( } & \multirow{3}{*}{33} & Лактоза & 12 \\
\hline & & & Трегалоза & 19 \\
\hline & & & Мальтоза & 7 \\
\hline \multirow{3}{*}{2} & \multirow{3}{*}{$95 / 5$} & \multirow{3}{*}{44} & Лактоза & 16 \\
\hline & & & Трегалоза & 28 \\
\hline & & & Мальтоза & 12 \\
\hline \multirow{3}{*}{3} & \multirow{3}{*}{$85 / 15$} & \multirow{3}{*}{57} & Лактоза & 39 \\
\hline & & & Трегалоза & 43 \\
\hline & & & Мальтоза & 35 \\
\hline \multirow{3}{*}{4} & \multirow{3}{*}{$70 / 30$} & \multirow{3}{*}{$\begin{array}{c}71 \\
\text { Ускладнення при } \\
\text { фрільтрації 0,22 мкм }\end{array}$} & Лактоза & 46 \\
\hline & & & Трегалоза & 51 \\
\hline & & & Мальтоза & 42 \\
\hline
\end{tabular}

Як модель для експерименту обрано концентрацію фроссроліпідів 15 мг/мл. Було досліджено ліпосоми із складом мембрани фросфратидилхолін / холестерин у масовому співвідношенні: 85/15; 80/20; 75/25; 70/30. Різниця в значені рН при створені «хімічного градієнта» склала 2,3 одиниці. Гомогенізацію проводили методом високого тиску до досягнення розміру часток 90-120 нм, який є прийнятним у фрармацевтичній промисловості як усереднений розмір ліпосом. Завантажували ліпосоми після проведення ультрасрільтрації іринотеканом до загальної кон- центрації 2 мг/мл, інкубація тривала 12 год. У таблиці 2 наведено результати експерименту.

Результати таблиці 2 підтверджують дані скринінгового експерименту - незважаючи на високий ступінь інкапсуляції, при співвідношенні ліпідів фросфратидилхолін / холестерин 75/25 та 70/30 неможливо позбутися часток розміром більше 220 нм. Мембрана із співвідношенням ліпідів фроссратидилхолін / холестерин 80/20 підтвердила ступінь інкапсуляції іринотекану - 79 \%, поруч із технологічною перевагою - відсутністю часток більше 1000 нм. Для подальшої

Таблиця 2. Характеристики отриманих ліпосом при різному співвідношенні фросфатидилхолін / холестерин

\begin{tabular}{|c|c|c|c|c|c|}
\hline $\begin{array}{c}\text { № } \\
\text { 3/п }\end{array}$ & $\begin{array}{c}\text { Склад ліпідів: } \\
\text { фосоратидилхолін / } \\
\text { холестерин, \% масові }\end{array}$ & $\begin{array}{c}\text { Кількість } \\
\text { циклів } \\
\text { екструзій }\end{array}$ & $\begin{array}{c}\text { Розмір } \\
\text { ліпосом, нм }\end{array}$ & $\begin{array}{c}\text { Ступінь } \\
\text { інкапсуляції } \\
\text { іринотекану, \% }\end{array}$ & Примітка \\
\hline 1 & $85 / 15$ & 6 & 86 & 63 & $\begin{array}{c}\text { Частки більше } \\
220 \text { нм відсутні }\end{array}$ \\
\hline 2 & $80 / 20$ & 7 & 108 & 79 & $\begin{array}{c}\text { Частки більше } \\
220 \text { нм відсутні }\end{array}$ \\
\hline 3 & $75 / 25$ & 12 & 131 & 87 & Наявні частки більше \\
1000 нм
\end{tabular}

ISSN 2312-0967. Фармацевтичний часопис. 2017. № 1 
оптимізації складу ліпосом доцільно обрати мембрану із співвідношенням ліпідів фросфратидилхолін / холестерин 80 / 20 як найбільш перспективну.

Можна очікувати, що отриманий ступінь інкапсуляції можна покращити за рахунок дослідження таких показників ліпосомальної системи, як концентрація ліпідів, різниці в значені рН при створені «хімічного градієнта». Також необхідно проводити дослідження впливу кріопротекторів на процес ліофілізації ліпосом поруч із оптимізацією режиму ліофільного сушіння наночасток.

Висновки. 1. Проведено скринінговий експеримент $з$ пошуку оптимального складу ліпідної мембрани та трьох типів кріопротекторів. Визначено пер-
Фармацевтична технологія, біофармація, гомеопатія Pharmaceutical technology, biopharmacy, homeopathy спективний склад ліпідів для подальшого дослідження в більш вузькому діапазоні співвідношення фросфратидилхолін / холестерин.

2. Досліджено ліпосомальні мембрани із співвідношенням ліпідів фроссратидилхолін / холестерин: 85/15; 80/20; 75/25; 70/30 за показником розміру ліпосом та інкапсуляції іринотекану в ліпосоми. Експериментально доведено склад оптимального 3 точки зору ступеня інкапсуляції та технологічної придатності мембрани, із співвідношенням фоосоатидилхолін / холестерин 80/20 \% масових.

3. Визначено шляхи покращення ступеня інкапсуляції для ліпосом з обраною ліпідною мембраною.

\title{
ИССЛЕДОВАНИЕ СОСТАВА ЛИПИДНОЙ МЕМБРАНЫ ПРИ СОЗДАНИИ ЛИПОСОМ С ИРИНОТЕКАНОМ
}

\author{
А. В. Стадниченко ${ }^{1}$, Ю. М. Краснопольский ${ }^{2}$, Т. Г. Ярних ${ }^{1}$ \\ ${ }^{1}$ Национальный фрармацевтический университет, Харьков \\ ${ }^{2}$ Национальный технический университет «Харьковский политехнический институт», Харьков \\ alstn@mail.ru
}

Цель работы. Определить влияние состава липидной мембраны на степень инкапсуляции и размер наночастиц при разработке липосом с иринотеканом.

Материалы и методы. Использовали реактивы фрирмы Lipoid (Германия) и Sigma-Aldrich (США), приборы: Buchi 210, Zetasizer Nano ZS, Minim2 с кассетами с верхним пределом отсечения 30 кДа, ВЭЖX Shimadzu LC-20. Липосомы с иринотеканом получали методом «химического градиента».

Результаты и обсуждение. Для создания липосом с иринотеканом были исследованы липидные мембраны с различным соотношением фоссратидилхолин / холестерин. Определено, что при увеличении массового содержания холестерина в мембране улучшается степень инкапсуляции иринотекана при использовании метода «химического градиента». С другой стороны, при массовом соотношении фросфатидилхолин / холестерин 75/25 и 70/30 невозможно избавиться от частиц с размерами более 1000 нм, что недопустимо с точки зрения применения технологии для производства готового липосомального препарата.

Выводы. Проведен эксперимент по исследованию оптимального состава липидной мембраны с использованием трех типов криопротекторов. Исследованы липосомальные мембраны с соотношением липидов фросфратидилхолин / холестерин: 85/15; 80/20; 75/25; 70/30 по показателю размера липосом и инкапсуляции иринотекана в липосомы. Доказано, что оптимальным являются состав липосом с соотношением липидов 80/20 соответственно. Намечены пути повышения степени инкапсуляции.

Ключевые слова: липосомы; иринотекан; липидный бислой; фосфатидилхолин; холестерин; гомогенизация высоким давлением.

\section{RESEARH OF THE LIPID MEMBRANE COMPOSITION DURING LIPOSOMAL IRINOTECAN CREATION}

\author{
O. V. Stadnichenko ${ }^{1}$, Y. M. Krasnopolsky², T. G. Yarnih ${ }^{1}$ \\ ${ }^{1}$ National University of Pharmacy, Kharkiv \\ 2 National Technical University «Kharkiv Polytechnic Institute», Kharkiv \\ alstn@mail.ru
}

The aim of the work. Research the effect of lipid membrane composition on the encapsulation degree and the size of nanoparticles in the pharmaceutical development of liposomal irinotecan.

Materials and Methods. Reagents were purchased from Lipoid, Germany and Sigma-Aldrich, USA. The following instruments were used: Buchi 210, Zetasizer Nano ZS, Minim2 with cassettes with an upper cut-off limit of $30 \mathrm{kDa}$, Shimadzu LC-20 HPLC. Liposomes with irinotecan were obtained by the "chemical gradient" technology.

ISSN 2312-0967. Pharmaceutical review. 2017. № 1 
Фармацевтична технологія, біофармація, гомеопатія

Pharmaceutical technology, biopharmacy, homeopathy

Results and Discussion. For purposes of liposomal irinotecan creation, lipid membranes with different phosphatidylcholine / cholesterol ratio were studied. It was determined that increasing of the cholesterol weight ratio in the membrane, improves the encapsulation of irinotecan when a «chemical gradient» method was used. On the other hand, at a mass ratio of phosphatidylcholine / cholesterol 75/25 and 70/30 it was impossible to avoid particles larger than $1000 \mathrm{~nm}$ formation, that is unacceptable from the position of industrial technology application.

Conclusions. An experiment was performed to research the optimal composition of the lipid membrane using three types of cryoprotectants. It was studied the influence of liposomal membranes with the ratio of lipids phosphatidylcholine $/$ cholesterol: 85/15; 80/20; 75/25; 70/30 on liposomes size and encapsulation degree. The ratio of 80/20 was defined as optimum for obtaining liposomes with irinotecan. Ways of improving of irinotecan encapsulation into liposomes were outlined.

Key words: liposomes; Irinotecan; lipid bilayer; phosphatidylcholine; cholesterol; high pressure homogenization.

\section{Список літератури}

1. Sessa G. Phospholipid spherules (liposomes) as a model for biological membranes / G. Sessa, G. Weissmann // J. Lipid. Res. - 1968. - Vol. 9, №3. - P. 310-318.

2. Liposomal drug delivery: a versatile platform for challenging clinical applications / A. Madni, M. Sarfraz, M. Rehman [et. al.] // J. Pharm. Pharm. Sci. -2014. - Vol. 17. - № 3. - P. 401-426.

3. Швец В. И. Липосомальная платсрорма для создания низкотоксичных противоопухолевых препаратов / В. И. Швец // Вестник МИТХТ. -2009. - № 4. - С. 4-25.

4. Исследование методов включения лекарственных субстанций В липосомальные наночастицы / А. Е. Шахмаев, А. Г. Кацай, В. В. Прохоров // Ремедиум. - 2015. - № 12. - С. 26-59.

5. Дудниченко А. В. Липосомальные лекарственные препараты в эксперименте и клинике / А. В. Дудниченко, Ю. М. Краснопольский, В. И. Швец. - Харьков : РАКаравелла, 2001. - 136 с.

6. Mechanisms of reduction of antitumor drug toxicity by liposome encapsulation / Y. E. Rahman, W. R. Hanson, J. Bharucha [et. al.] // Ann. N. Y. Acad. Sci. - 1978. Vol. 308. - P. 325-342.

7. Matsumura Y. A new concept for macromolecular therapeutics in cancer chemotherapy: mechanism of tumoritropic accumulation of proteins and the antitumor agent smancs / Y. Matsumura, H. Maeda // Cancer Research. - 1986. -

\section{References}

1. Sessa G, Weissmann G. Phospholipid spherules (liposomes) as a model for biological membranes. J Lipid Res. 1968; 9(3): 310-318.

2. Madni A, Sarfraz M, Rehman M, Ahmad M, Akhtar N, Ahmad $S$ et al. Liposomal drug delivery: a versatile platform for challenging clinical applications. J Pharm Pharm Sci. 2014;17(3): 401-26. Available from: https://www.ncbi. nlm.nih.gov/pubmed/25224351

3. Shvets VI. Liposomalnaya platforma dlya sozdaniya nizkotoksichnikh protivoopuholevih preparatov. Vestnik MITHT. 2014;4: 4-25; Russian.

4. Shahmaev AY, Katsai AL, Prohorov VV, Stadnichenko AV, Balabanyan VY, Krasnopolskiy YM et al. Investigation of the methods of inclusion of medicinal substances in liposomal nanoparticles. Remedium. 2015;12: 26-59. Available from:
№ 46. - Р. 6387-6392.

8. Стадниченко А. В. Технология получения липосомальных фрорм иринотекана (обзор) / А. В. Стадниченко, Ю. М. Краснопольский, В.И.Швец // Биофрармацевтический журнал. -2014. - Т. 6, № 6. C. 3-9.

9. Official FDA site. FDA prescribing information. Irinotecan. - 2010. Access mode - http://www.accessdata.fda.gov/ drugsatfda_docs/label/2014/020 571s048lbl.pdf

10. Paulik A. Predictors of Irinotecan toxicity and efficancy in treatment of metastatic colorectal cancer / A. Paulik, J. Grim, S. Filip // Acta Medica. - 2012. -Vol. 55, №4. P. 153-159.

11. N. Kopjar. Irinotecan Toxicity to Human Blood Cells in vitro: Relationship between Various Biomarkers / N. Kopjar N., D. Zeljezic, A. Vrdoljak // Basic and Clinical Pharmacology and Toxicology. -2007. - Vol. 100, № 6. - P. 403-413. 12. Стадниченко А. В. Разработка и валидация методики определения степени инкапсуляции иринотекана гидрохлорида в липосомы / А. В. Стадниченко, Ю. М. Краснопольский, В. И. Швец // Биофармацевтический журнал. -2015. -T. 7, № 1. - C. 53-55.

13. Li J. A review on phospholipids and their main applications in drug delivery systems / J. Li, X. Wang, T. Zhang // Asian Journal of Pharmaceutical Sciences. - 2014. - № 1. - P. 1-18.

http://elibrary.ru/item.asp?id=25280721; Russian

5. Dudnichenko AV, Krasnopolskiy YM, Shvets VI. Liposomal drugs in the experiment and clinic. [Липосомальные лекарственные препараты в эксперименте и клинике] Kharkov: RA-Karavella; 2001. Russian.

6. Rahman YE, Hanson WR, Bharucha J, Ainsworth EJ, Jaroslow BN. Mechanisms of reduction of antitumor drug toxicity by liposome encapsulation. Ann. N. Y. Acad Sci. 1978;308: 325-42. Available from: https://www.ncbi.nlm. nih.gov/pubmed/279296

7. Matsumura Y, Maeda H. A new concept for macromolecular therapeutics in cancer chemotherapy: mechanism of tumoritropic accumulation of proteins and the antitumor agent smancs. Cancer Research. 1986;46: 6387-92. Available from: https://www.ncbi.nlm.nih.gov/pubmed/2946403

ISSN 2312-0967. Фармацевтичний часопис. 2017. № 1 
Фармацевтична технологія, біофармація, гомеопатія

Pharmaceutical technology, biopharmacy, homeopathy

8. Stadnichenko AV, Krasnopolskiy YM, Shvets VI. The technology of obtaining liposomal forms of irinotecan (review). Biofarmacevtichesky zhurnal. 2014;6(6): 3-9. Available from: http:// uww.biopharmj.ru/ojs238/index.php/ biopharmj/article/view/249

9. Official FDA site. FDA prescribing information. Irinotecan. 2010. Available from: - http://www.accessdata.fda.gov/ drugsatfda docs/label/2014/020 571s048lbl.pdf

10. Paulik A, Grim J, Filip S. Predictors of Irinotecan toxicity and efficacy in treatment of metastatic colorectal cancer. Acta Medica. 2012;55(4): 153-59. Available from: https:// www.ncbi.nlm.nih.gov/pubmed/23631285

11. Kopjar N, Zeljezic D, Vrdoljak A. Irinotecan Toxicity to Human Blood Cells in vitro: Relationship between Various
Biomarkers. Basic and Clinical Pharmacology and Toxicology. 2007;100(6): 403-13. Available from: https://www. ncbi.nlm.nih.gov/pubmed/17516995

12. Stadnichenko AV, Krasnopolskiy YM, Shvets VI. Development and validation of the procedure for determining the degree of encapsulation of irinotecan hydrochloride in liposomes. Biofarmacevtichesky zhurnal. 2015;7(1): 53-55. Available from: http://elibrary.ru/item.asp?id=23787998.

13. Li J, Wang $X$, Zhang T. A review on phospholipids and their main applications in drug delivery systems. Asian journal of pharmaceutical sciences. 2014;1: 1-18. Available from: http://www.sciencedirect.com /science/article/pii/ S1818087614000725

Отримано 11.01.2017

ISSN 2312-0967. Pharmaceutical review. 2017. № 1 